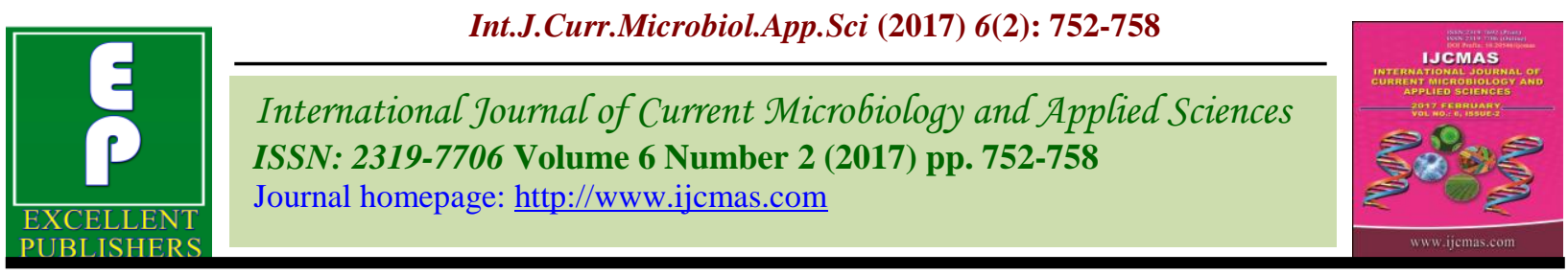

Original Research Article

http://dx.doi.org/10.20546/ijcmas.2017.602.083

\title{
Effect of Feed Additives on Nutrient Intake and Feed Efficiency of Lactating Crossbred Cows
}

\author{
Mayank Dubey, Vivek Pratap Singh*, R.K. Pandey and A.K. Chaubey \\ Department of Animal Husbandry and Dairying, Institute of Agricultural Sciences, \\ Banaras Hindu University, Varanasi-221005, India
}

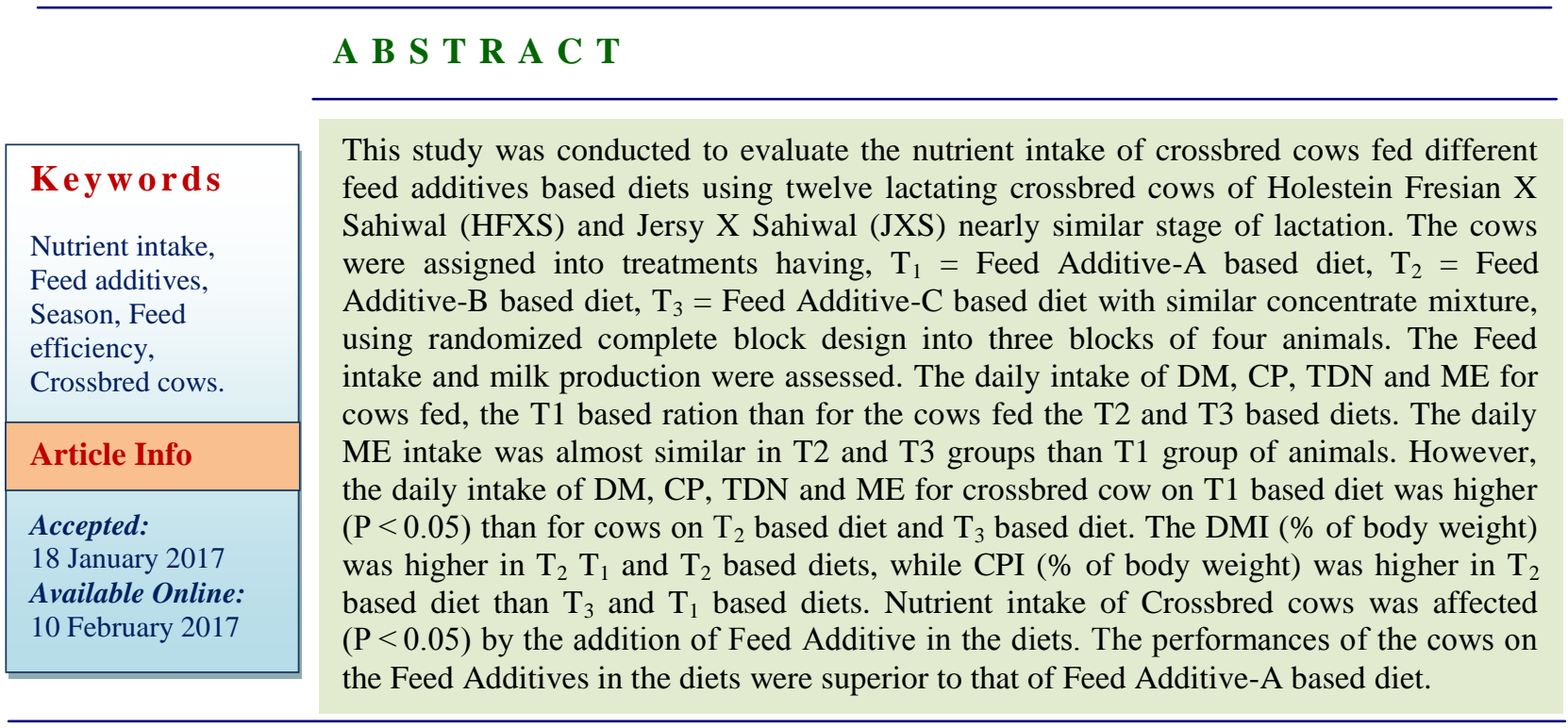

\section{Introduction}

The nutritional needs of dairy animals with respect to energy, protein, minerals and vitamins have long been known, and these have been refined in recent decades. Various requirement determination systems exist in different countries for ruminants and nonruminants, which were originally designed to assess the nutritional and productive consequences of different feeds for the animal once intake was known. In modern-day farming, the nutritional requirements of farm animals are well understood and all requirements can be met through direct dietary supplementation of the limiting nutrients in concentrated form. Feeding high producing cows continues to challenge dairy farmers and nutritionists.

Feed additives are a group of feed ingredients that can cause a desired animal response in a non-nutrient role such as $\mathrm{pH}$ shift, growth, or metabolic modifier (Hutjens, 1991). Feed additives provide a mechanism by which such dietary deficiencies can be addressed which benefits not only the nutrition and thus the growth rate of the animal concerned, but also its health and welfare. Nutritional quality of a feed is influenced not only by nutrient content but also by many other aspects such as, feed presentation, hygiene, content of anti- 
nutritional factors, digestibility, palatability and effect on intestinal health to name a few. Feed additives provide a mechanism by which such dietary deficiencies can be addressed which benefits not only the nutrition and thus the growth rate of the animal concerned, but also its health and welfare. In addition, the beneficial effect of probiotics could be produced in two ways. They could operate by: (1) Suppressing harmful bacteria; this could manifest itself in reduced numbers of bacteria or in a decreased concentration of harmful metabolites such as enterotoxin. (2) Stimulation of bacteria which are engaged in beneficial activities such as production of essential nutrients like vitamins or in digestion of food components (Mulder, 1991). In view of the aforesaid, the present research work was planned at the dairy farm, Banaras Hindu University, Varanasi. The plan of work comprised finding out the effect of feed additives and their impact on nutrient intake of lactating crossbred cows maintained at the dairy farm.

\section{Materials and Methods}

This investigation was undertaken to study the nutrient intake of crossbred lactating cows on diet containing different feed additives at dairy farm, of Banaras Hindu University, Varanasi. The trial was conducted on 12 crossbred cows Holestein Fresian X Sahiwal (HFXS) and Jersy X Sahiwal (JXS) nearly similar stage of lactation were selected from the herd maintained at the dairy farm. The animals were quite healthy and their calves have been weaned soon after birth. All the 12 crossbred cows were randomly divided into 3 groups with 4 animals in each group according to their milk production and body weight to maintain the similarity in the trial. Daily feed intake was recorded in terms of DMI, DMI (\% of BW), CP intake, CP intake (\% of BW), TDN intake and ME intake and data were analyzed using the general linear model of the Statistical Analysis System
(SAS 2002). Duncan's multiple range tests was used to separate treatment means. The response variables were analyzed using the statistical model:

$Y i j k=\mu+P i+\alpha j+\beta(x i j k-X)+.\epsilon_{i j k}$,

\section{Results and Discussion}

\section{Dry matter intake (kg/day)}

Results regarding average dry matter intake (DMI) of the animals is shown in table 1, and daily dry matter intake was recorded $8.84+$ $0.34,8.77+0.30$ and $9.12+0.22 \mathrm{~kg} / \mathrm{d}$ in $\mathrm{T}_{1}$, $\mathrm{T}_{2}$ and $\mathrm{T}_{3}$ groups respectively (Table 1 ) in summer season. However, the DMI in rainy season was $2.84+0.09,3.10+0.13$ and $2.84+$ $0.12 \mathrm{~kg} / \mathrm{d}$ in $\mathrm{T}_{1}, \mathrm{~T}_{2}$ and $\mathrm{T}_{3}$ groups respectively (Table 1). While DMI in winter season DMI was $2.84+0.09,3.10+0.13$ and $2.84+0.12$ $\mathrm{kg} / \mathrm{d}$ in $\mathrm{T}_{1}, \mathrm{~T}_{2}$ and $\mathrm{T}_{3}$ groups respectively (Table 1). The dry matter intake was highest in winter season in all the groups and group $\mathrm{T}_{1}$ was highest followed by $\mathrm{T}_{3}$ and $\mathrm{T}_{2}$ groups in rainy and winter season in terms of daily dry matter intake but in summer season $\mathrm{T}_{3}$ group was higher than $T_{1}$ and $T_{2}$ groups. Differences between the groups were not significant $(\mathrm{P}>0.05)$. The results in this trial confirm those of Williams et al., (1991), Wohlt et al., (1991, 1998), Robinson and Garrett (1999), and Dann et al., (2000), who observed that feed additives improvement in DM intake when lactating cows were fed. Supplementation with a blend of cinnamaldehyde and eugenol as a feed additive can increase DMI and milk production in lactating dairy cows (Wall 2014). However, Aikman et al., (2008) observed no difference in DM intake between the control and treated cows.

When dry matter in take compared between two breeds during summer season the DMI was higher in $\mathrm{B}_{1}$ breed $(9.04+0.22)$ than $\mathrm{B}_{2}$ breed $(8.77+0.23)$. Again in rainy season 
DMI was higher in B1 breed $(9.13+0.04)$ than B2 breed $(9.10+0.17)$ but in winter season $\mathrm{B}_{2}$ breed was higher $(9.34+0.21)$ than $\mathrm{B}_{1}$ breed $(8.95+0.21)$ in DMI (Table 2). These results are in agreement with those obtained by Ballantine et al., (2002) who reported that cows fed organic mineral consumed more DM than cows receiving inorganic mineral.

\section{Dry matter intake per cent of body weight}

DMI per cent of body of cows to be expressed as changes in the DMI was observed to be $3.01+0.03,2.95+0.05$ and $2.95+0.10 \mathrm{~kg} / \mathrm{d}$ in $\mathrm{T}_{1}, \mathrm{~T}_{2}$ and $\mathrm{T}_{3}$ groups respectively (Table 1 ) in summer season. In rainy season DMI per cent of body weight was $2.84+0.09,3.10+$ 0.13 and $2.84+0.12 \mathrm{~kg} / \mathrm{d}$ in $\mathrm{T}_{1}, \mathrm{~T}_{2}$ and $\mathrm{T}_{3}$ groups respectively (Table 1 ).

In winter season DMI per cent of body weight was $2.99+0.02,2.95+0.05$ and $2.97+0.03$ $\mathrm{kg} / \mathrm{d}$ in $\mathrm{T}_{1}, \mathrm{~T}_{2}$ and $\mathrm{T}_{3}$ groups respectively (Table 1). DMI per cent of body weight was also highest in winter season in all the groups. Among all the groups during all three seasons $\mathrm{T}_{2}$ group was highest in rainy season in respect of DMI per cent body weight. These observations were statistically similar between the groups in various treatments.

Results showed that DMI (\% body weight) in summer season was same as dry matter in take, $B_{1}$ breed was higher $(2.97 \pm 0.03)$ than $\mathrm{B}_{2}$ breed $(2.95 \pm 0.02)$ but in rainy and winter season pattern was vice-versa to DMI. In rainy season the DMI (\% body weight) $\mathrm{B}_{2}$ breed was higher $(2.98 \pm 0.12)$ than $\mathrm{B}_{1}$ breed $(2.90 \pm 0.07)$ while in winter season it was higher in $\mathrm{B}_{1}$ breed $(3.00 \pm 0.07)$ than $\mathrm{B}_{2}$ breed $(2.97 \pm 0.02)$ (Table 2).

\section{Total crude protein intake (g/day)}

Total CP intake of the animals (g/day) is shown in table 1 and it intake was $1398.03 \pm$
$17.28,1395.15 \pm 9.04$ and $1405.58 \pm 11.83 \mathrm{~g} / \mathrm{d}$ in $\mathrm{T}_{1}, \mathrm{~T}_{2}$ and $\mathrm{T}_{3}$ groups respectively (Table 1) in summer season. In rainy season CP intake of animals was 1158.08 $\pm 21.21,1177.93 \pm$ 21.75 and $1181.53 \pm 22.91 \mathrm{~g} / \mathrm{d}$ in $\mathrm{T}_{1}, \mathrm{~T}_{2}$ and $\mathrm{T}_{3}$ groups respectively (Table 1 ). In winter season CP intake was 1309.70 \pm 12.46, $1276.80 \pm 33.90$ and $1187.73 \pm 37.04 \mathrm{~g} / \mathrm{d}$ in $\mathrm{T}_{1}, \mathrm{~T}_{2}$ and $\mathrm{T}_{3}$ groups respectively (Table 1)The CP intake was highest in summer season in all the groups and group T3 was highest in summer and rainy season while in winter season $T_{1}$ group was higher than $T_{2}$ and $\mathrm{T}_{3}$ groups. Differences between the groups were not significant $(\mathrm{P}>0.05)$ but within the groups it was highly significant. In accordance with the present results agrees with the work of Allen (2000) who summarized that increasing CP content of the diets can increase DMI of lactating cows. These results are in agreement with the reports of Sarker (2010) who reported mixed additives showed better nutrient utilization.

The comparative study of two breeds showed that $\mathrm{CP}$ in take in summer season was almost similar in both breeds but in rainy season it was slightly higher in $\mathrm{B}_{1}$ breed (1173.47 \pm 18.95) than $B_{2}$ breed $(1171.55 \pm 16.19)$ and winter season $\mathrm{CP}$ in take was higher in $\mathrm{B}_{2}$ breed $(1279.37 \pm 15.45)$ than $\mathrm{B}_{1}$ breed (1236.78 \pm 14.38) (Table 2).

\section{Crude protein intake per cent of body weight}

CP intake per cent of body weight was observed to be $376.40+3.87,391.52+4.05$ and $379.27+6.04 \mathrm{~g} / \mathrm{d}$ in $\mathrm{T}_{1}, \mathrm{~T}_{2}$ and $\mathrm{T}_{3}$ groups respectively (Table 1 ) in summer season. In rainy season $\mathrm{CP}$ intake per cent of body weight was $341.30+2.69,342.45+3.87$ and $332.20+5.99 \mathrm{~g} / \mathrm{d}$ in $\mathrm{T}_{1}, \mathrm{~T}_{2}$ and $\mathrm{T}_{3}$ groups respectively (Table 1 ). In winter season $\mathrm{CP}$ intake per cent of body weight was $338.92+$ $3.02,362.80+4.36$ and $358.80+5.02 \mathrm{~g} / \mathrm{d}$ in $\mathrm{T}_{1}, \mathrm{~T}_{2}$ and $\mathrm{T}_{3}$ groups respectively (Table 1 ). 
$\mathrm{CP}$ intake per cent of body weight was also highest in summer season in all the treatment groups. Among the entire groups $\mathrm{T}_{2}$ group was highest in summer season followed by $\mathrm{T}_{3}$ and $\mathrm{T}_{2}$ in terms of CP intake per cent body weight. These observations were statistically significant $(\mathrm{P}>0.05)$ between the groups in winter treatments but in rainy and summer results were not significant.

$\mathrm{CP}$ in take (\% body weight) was higher $\mathrm{B}_{1}$ breed $(384.91+4.33)$ than $\mathrm{B}_{2}$ breed $(379.88+4.80)$ in summer season but in rainy season same was also higher in $\mathrm{B}_{1}$ breed $(341.71+3.31)$ than $\mathrm{B}_{2}$ breed $(335.58+4.11)$ and in winters the CP in take (\% body weight) was higher in $\mathrm{B}_{2}$ breed $(354.45+6.05)$ than $\mathrm{B}_{1}$ breed $(352.61+5.29)$ (Table 2$)$.

\section{TDN intake (kg/day)}

The TDN intake response of cow to control and experimental diets The average TDN intake $\mathrm{kg} /$ day was $7.50 \pm 0.07,7.58 \pm 0.10$ and $7.58 \pm 0.07 \mathrm{~kg} / \mathrm{d}$ in groups $\mathrm{T}_{1}, \mathrm{~T}_{2}$ and $\mathrm{T}_{3}$ respectively (Table 1) in summer season.

In rainy season TDN intake was $6.91 \pm 0.15$, $6.81 \pm 0.15$ and $6.75 \pm 0.19 \mathrm{~kg} / \mathrm{d}$ in $\mathrm{T}_{1}, \mathrm{~T}_{2}$ and $\mathrm{T}_{3}$ groups respectively (Table 1 ). In winter season TDN intake was 7.41 $\pm 0.03,7.22 \pm$ 0.20 and $7.14 \pm 0.05 \mathrm{~kg} / \mathrm{d}$ in $\mathrm{T}_{1}, \mathrm{~T}_{2}$ and $\mathrm{T}_{3}$ groups respectively (Table 1 ). TDN intake was higher in summer season among all the groups followed by winter and rainy season. Here again the values in $T_{2}$ and $T_{3}$ groups were significantly higher than $T_{1}$ group and were almost similar in summer season. But in rainy and winter season TDN intake was highest in $T_{1}$ group followed by $T_{2}$ and $T_{3}$ groups. There was no significant difference in TDN intake among the groups. These results are in accordance with those obtained by
Bendary et al., (2013) who reported that the seaweed treatment showed significantly $(\mathrm{P}<0.05)$ highest average daily intake of TDN while the lowest intake was in control treatment.

The comparison of TDN in take between two breeds showed that, in summer season breed $\mathrm{B}_{1}$ was better $(7.59 \pm 0.07)$ than $\mathrm{B}_{2}$ breeds $(7.52 \pm 0.05)$ and in winter season also $B_{1}$ breed was better $(7.30 \pm 0.12)$ than $\mathrm{B}_{2}$ breed $(7.20 \pm 0.08)$ but in rainy season TDN in take was higher in $\mathrm{B}_{2}$ breed $(6.88 \pm 0.09)$ than $\mathrm{B}_{1}$ breed $(6.77 \pm 0.16)$ (Table 2).

\section{ME intake (Mcal/day)}

The ME intake Mcal/day was $18.85 \pm 0.03$, $19.18 \pm 0.32$ and $19.42 \pm 0.27$ in groups $\mathrm{T}_{1}, \mathrm{~T}_{2}$ and $\mathrm{T}_{3}$ respectively (Table 1) in summer season. In rainy season ME intake was $18.12 \pm$ $0.15,18.23 \pm 0.15$ and $19.42 \pm 0.09 \mathrm{Mcal} / \mathrm{d}$ in $\mathrm{T}_{1}, \mathrm{~T}_{2}$ and $\mathrm{T}_{3}$ groups respectively (Table 1 ). In winter season ME intake was $18.47 \pm 0.07$, $18.85 \pm 0.10$ and $18.86 \pm 0.13 \mathrm{Mcal} / \mathrm{d}$ in $\mathrm{T}_{1}, \mathrm{~T}_{2}$ and $\mathrm{T}_{3}$ groups respectively (Table 1 ). Results showed that the ME intake was also highest in summer season among all the groups followed by winter and rainy season. The values in T3 group were significantly higher than $T_{2}$ and $T_{1}$ groups in all three seasons. There was no significant difference in TDN intake among the groups. Energy in take was higher in $B_{2}$ breed than $B_{1}$ breed in all three seasons (Table 2).

These results are agreement with Michael (2007) reported that the supplementation of feed additive in lactating cow rations are beneficial for nutrient intake ant their utilization and also improved performance of cows. 
Table.1 Seasonal effect of various feed additives on feed intake of crossbred cows

\begin{tabular}{|c|c|c|c|c|c|c|}
\hline $\begin{array}{c}\text { Treatment } \\
\text { groups }\end{array}$ & I Intake (kg/day) & $\begin{array}{l}\text { DM intake } \\
\text { (\% of BW) }\end{array}$ & $\begin{array}{c}\text { CP intake } \\
\text { (g/day) }\end{array}$ & $\begin{array}{c}\text { CP intake } \\
(\% \text { of } \mathrm{BW})\end{array}$ & $\begin{array}{c}\text { TDN intake } \\
\text { (kg/day) }\end{array}$ & intake (Mcal/day) \\
\hline \multicolumn{7}{|c|}{ Summer Season } \\
\hline $\mathrm{T}_{1}$ & $8.84 \pm 0.34 \mathrm{a}$ & $2.99 \pm 0.02 \mathrm{a}$ & $1398.03 \pm 17.28 \mathrm{a}$ & $376.40 \pm 3.87 \mathrm{a}$ & $7.50 \pm 0.07 \mathrm{a}$ & $18.85 \pm 0.03 \mathrm{a}$ \\
\hline $\mathrm{T}_{2}$ & $8.77 \pm 0.30 \mathrm{a}$ & $2.95 \pm 0.05 \mathrm{a}$ & $1395.15 \pm 9.04 \mathrm{a}$ & $391.52 \pm 4.05 \mathrm{a}$ & $7.58 \pm 0.10 \mathrm{a}$ & $19.18 \pm 0.32 \mathrm{a}$ \\
\hline $\mathrm{T}_{3}$ & $9.12 \pm 0.22 \mathrm{a}$ & $2.97 \pm 0.03 \mathrm{a}$ & $1405.58 \pm 11.83 \mathrm{a}$ & $379.27 \pm 6.04 \mathrm{a}$ & $7.58 \pm 0.07 \mathrm{a}$ & $19.42 \pm 0.27 \mathrm{a}$ \\
\hline \multicolumn{7}{|c|}{ Rainy Season } \\
\hline $\mathrm{T}_{1}$ & $9.28 \pm 0.20^{\mathrm{a}}$ & $2.84 \pm 0.09^{\mathrm{a}}$ & $1158.08 \pm 21.21^{\mathrm{a}}$ & $341.30 \pm 2.69^{\mathrm{a}}$ & $6.91 \pm 0.15^{\mathrm{a}}$ & $18.12 \pm 0.15^{\mathrm{a}}$ \\
\hline $\mathrm{T}_{2}$ & $8.87 \pm 0.08^{\mathrm{a}}$ & $3.10 \pm 0.13^{\mathrm{a}}$ & $1177.93 \pm 21.75^{\mathrm{a}}$ & $342.45 \pm 3.87^{\mathrm{a}}$ & $6.81 \pm 0.15^{\mathrm{a}}$ & $18.23 \pm 0.15^{\mathrm{a}}$ \\
\hline $\mathrm{T}_{3}$ & $9.18 \pm 0.04^{\mathrm{a}}$ & $2.84 \pm .12^{\mathrm{a}}$ & $1181.53 \pm 22.91^{\mathrm{a}}$ & $332.20 \pm 5.99^{\mathrm{a}}$ & $6.75 \pm 0.19^{\mathrm{a}}$ & $18.51 \pm 0.09^{\mathrm{a}}$ \\
\hline \multicolumn{7}{|c|}{ Winter Season } \\
\hline $\mathrm{T}_{1}$ & $9.37 \pm 0.11 \mathrm{a}$ & $3.01 \pm 0.03 \mathrm{a}$ & $1309.70 \pm 12.46 a$ & $338.92 \pm 3.02 b$ & $7.41 \pm 0.03 \mathrm{a}$ & $18.47 \pm 0.07 \mathrm{a}$ \\
\hline $\mathrm{T}_{2}$ & $8.89 \pm 0.42 \mathrm{a}$ & $2.95 \pm 0.05 \mathrm{a}$ & $1276.80 \pm 33.90 \mathrm{ab}$ & $362.80 \pm 4.36 \mathrm{a}$ & $7.22 \pm 0.20 \mathrm{a}$ & $18.85 \pm 0.10 \mathrm{a}$ \\
\hline $\mathrm{T}_{3}$ & $9.17 \pm 0.16 \mathrm{a}$ & $2.95 \pm 0.10 \mathrm{a}$ & $1187.73 \pm 37.04 b$ & $358.87 \pm 5.02 \mathrm{a}$ & $7.14 \pm 0.05 a$ & $18.86 \pm 0.13 \mathrm{a}$ \\
\hline
\end{tabular}

Means within the same column, with the same letters are not significantly different $(\mathrm{P}<0.05)$

Table.2 Seasonal variation due to breeds on feed intake in different groups

\begin{tabular}{|c|c|c|c|c|c|c|}
\hline Breed & $\begin{array}{c}\text { DM Intake } \\
\text { (kg/day) }\end{array}$ & $\begin{array}{l}\text { DM intake } \\
\text { (\% of BW) }\end{array}$ & $\begin{array}{c}\text { CP intake } \\
\text { (g/day) }\end{array}$ & $\begin{array}{l}\text { CP intake } \\
(\% \text { of BW) }\end{array}$ & N intake (kg/day) & I intake (Mcal/day \\
\hline \multicolumn{7}{|c|}{ Summer Season } \\
\hline $\mathrm{B}_{1}$ & $9.04 \pm 0.22 \mathrm{a}$ & $2.97 \pm 0.03^{\mathrm{a}}$ & $1399.53 \pm 11.75 a$ & $384.91 \pm 4.33 \mathrm{a}$ & $7.59 \pm 0.07 a$ & $19.02 \pm 0.17 \mathrm{a}$ \\
\hline $\mathrm{B}_{2}$ & $8.77 \pm 0.23 \mathrm{a}$ & $2.95 \pm 0.02 \mathrm{a}$ & $1399.63 \pm 8.82 \mathrm{a}$ & $379.88 \pm 4.80 \mathrm{a}$ & $7.52 \pm 0.05 \mathrm{a}$ & $19.28 \pm 0.24 \mathrm{a}$ \\
\hline \multicolumn{7}{|c|}{ Rainy Season } \\
\hline $\mathrm{B}_{1}$ & $9.13 \pm 0.04^{\mathrm{a}}$ & $2.90 \pm 0.07^{\mathrm{a}}$ & $1173.47 \pm 18.95^{\mathrm{a}}$ & $341.71 \pm 3.31^{\mathrm{a}}$ & $6.77 \pm 0.16^{\mathrm{a}}$ & $18.23 \pm 0.16^{\mathrm{a}}$ \\
\hline $\mathrm{B}_{2}$ & $9.10 \pm 0.17^{\mathrm{a}}$ & $2.98 \pm 0.12^{\mathrm{a}}$ & $1171.55 \pm 16.19 \mathrm{a}$ & $335.58 \pm 4.11^{\mathrm{a}}$ & $6.88 \pm 0.09^{\mathrm{a}}$ & $18.34 \pm 0.07^{\mathrm{a}}$ \\
\hline \multicolumn{7}{|c|}{ Winter Season } \\
\hline $\mathrm{B}_{1}$ & $8.95 \pm 0.21^{\mathrm{a}}$ & $3.00 \pm 0.07 \mathrm{a}$ & $1236.78 \pm 41.38^{\mathrm{a}}$ & $352.61 \pm 5.29^{\mathrm{a}}$ & $7.30 \pm 0.12^{\mathrm{a}}$ & $18.71 \pm 0.12^{\mathrm{a}}$ \\
\hline $\mathrm{B}_{2}$ & $9.34 \pm 0.21 \mathrm{a}$ & $2.97 \pm 0.02 \mathrm{a}$ & $1279.37 \pm 15.45 \mathrm{a}$ & $354.45 \pm 6.05 \mathrm{a}$ & $7.20 \pm 0.08 \mathrm{a}$ & $18.75 \pm 0.10 \mathrm{a}$ \\
\hline
\end{tabular}

Means within the same column, with the same letters are not significantly different $(\mathrm{P}<0.05)$

Table.3 Overall efficiency of feed additives on feed intake into experimental groups of cows

\begin{tabular}{|c|c|c|c|c|c|c|}
\hline $\begin{array}{c}\text { Treatment } \\
\text { groups }\end{array}$ & $\begin{array}{c}\text { DM Intake } \\
\text { (kg/day) }\end{array}$ & $\begin{array}{c}\text { intake } \\
\text { of BW) }\end{array}$ & (\% intake & $\begin{array}{l}\text { CP intake } \\
(\% \text { of } \mathrm{BW})\end{array}$ & $\begin{array}{c}\text { TDN intake } \\
\text { (kg/day) }\end{array}$ & $\begin{array}{l}\text { ME intake } \\
\text { (Mcal/day) }\end{array}$ \\
\hline $\mathrm{T}_{1}$ & $9.16 \pm 0.14^{\mathrm{a}}$ & $2.95 \pm 0.03^{\mathrm{a}}$ & $1288.6 \pm 31.22^{\mathrm{a}}$ & $352.20 \pm 5.43^{b}$ & $7.27 \pm 0.09^{\mathrm{a}}$ & $18.48 \pm 0.10^{b}$ \\
\hline $\mathrm{T}_{2}$ & $8.85 \pm 0.16^{a}$ & $3.00 \pm 0.05^{\mathrm{a}}$ & $1283.2 \pm 29.52^{\mathrm{a}}$ & $365.59 \pm 6.43^{\mathrm{a}}$ & $7.20 \pm 0.12^{\mathrm{a}}$ & $18.84 \pm 0.18^{\mathrm{a}}$ \\
\hline $\mathrm{T}_{3}$ & $9.16 \pm 0.08^{\mathrm{a}}$ & $2.94 \pm 0.05^{\mathrm{a}}$ & $1258.2 \pm 34.23^{\mathrm{a}}$ & $356.78 \pm 6.53^{\mathrm{b}}$ & $7.16 \pm 0.12^{\mathrm{a}}$ & $18.84 \pm 0.12^{\mathrm{a}}$ \\
\hline
\end{tabular}

Means within the same column, with the same letters are not significantly different $(\mathrm{P}<0.05)$

Efficiency of feed additives on feed intake of cows

The overall efficiency of feed additives on feed intake into experimental groups of cows was determined in all three treatment groups during all the seasons of experimental trial and results showed in table 3 . The overall DMI was highest in $T_{1}$ group followed by $T_{3}$ and $\mathrm{T}_{2}$ groups. DMI (\% of body weight) was highest in $T_{2}$ group followed by $T_{1}$ and $T_{3}$ groups and in $\mathrm{CP}$ intake $\mathrm{T}_{1}$ group was highest followed by $\mathrm{T}_{2}$ and $\mathrm{T}_{3}$ groups. The $\mathrm{CP}$ intake (\% of Body weight) was highest in $\mathrm{T}_{2}$ group followed by $\mathrm{T}_{3}$ and $\mathrm{T}_{1}$ groups and the differences were statistically different $(\mathrm{P}<0.05)$. TDN intake was highest in $\mathrm{T}_{1}$ group followed by $\mathrm{T}_{2}$ and $\mathrm{T}_{3}$ groups and $\mathrm{ME}$ intake was highest and similar in $\mathrm{T}_{2}$ and $\mathrm{T}_{3}$ groups followed by $\mathrm{T}_{1}$ group. Accept CP intake (\% of BW) all other means were not statistically different within the groups $(\mathrm{P}<0.05)$. Vahora and Pandey (2006) used Jersey X Kankrej crossed lactating cows to evaluate DMI that 
was similar to present study, they observed a non significant difference for DMI.

In conclusion, results of the present study suggest the supplementation of feed additives in the diets increases in DMI, CP intake, total digestible nutrient intake, as well as $\mathrm{ME}$ intake and income over feed. The use of feed additives should be highly recommended as a feed supplement source in the ration of lactating dairy cows.

\section{References}

Allen, M.S. 2000. Effects of diet on shortterm regulation of feed intake by lactating dairy cattle. J. Dairy Sci., 83: 1598-1624.

Ballantine, H.T., Socha, M.T., Tomlinson, D.J., Johnson, A.B., Fielding, A.S., Shearer, J.K., and Van Amstel, S.R. 2002. Effects of feeding complexed zinc, manganese, copper, and cobalt to late gestation and lactating dairy cows on claw integrity, reproduction, and lactation performance. Prof. Anim. Sci., 18: 211.

Bendary, M.M., M.I., Bassiouni, M.F., Ali, H.M., Gaafar and A.Sh. Shamas. 2013. Effect of premix and seaweed additives on productive performance of lactating friesian cows. Int. Res. J. Agri. Sci., 1(1): 11-18.

Bezabih, M., Pellikaan, W.F., Tolera, A., and Hendriks, W.H. 2012. Estimation of feed intake and digestibility in cattle consuming low-quality tropical roughage diets using molasses-based nalkane boluses. Animal Feed Sci. Technol., 177(3/4): 161-171.

Dann, H.M., Drackley, J.K., McCoy, G.C., Hutjens, M.F. and Garrett, J.E. 2000. Effects of yeast culture (Saccharomyces cerevisiae) on prepartum intake and postpartum intake and milk production of Jersey cows. J. Dairy Sci., 83: 123-
127.

Emma, H., Wall, Perry, Doane, H., Shawn, S., Donkin, David Bravo. 2014. The effects of supplementation with a blend of cinnamaldehyde and eugenol on feed intake and milk production of dairy cows.

J. Dairy Sci., 97(9): 5709-5717.

Gupta, Nilin., Kumar, Anil., and Tiwari, D.P. 2005. Effect of herbs as a feed additive on nutrient utilization and growth in crossbred heifers fed paddy straw based rations. Indian J. Animal Sci., 75 (1):5255.

Hutjens, M.F. 1991. Feed additives. Vet Clinics North Am. Food Animal Practice, 7(2):525.

Jatkauskas, J., Vrotniakiene, V., and Urbsiene, D. 2010. Effects of a chemical additive on whole crop spring barley silage fermentation feed intake and milk production. Animal Husbandry, Scientific Articles. 55, 316.

Kim, H.S., Jung, H.Y., Lee, H.J., Ki, K.S., Cho, Y.M., Ahn, B.S., and Lee, S.S. 2002. The effect of feed additives supplement on prepartum and postpartum feed intake, milk production and metabolic disorders of dairy cows. J. Animal Sci. Technol., 44(5): 561-572.

Mulder, R.W.A.W. 1991. Probiotics as a tool against almonella contamination. Misset-World Poultry, 7(3): 60-68.

Robinson, P.H., and Garrett, J.E. 1999. Effect of yeast culture (Saccharomyces cerevisiae) on adaptation of cows to postpartum diets and on lactational performance. J. Animal Sci., 77, 988999.

Sarker, M.S.K., Ko, S.Y., Lee, S.M., Kim, G.M., Choi, J.K. and Yang, C.J. 2010. Effect of Different Feed Additives on Growth Performance and Blood Profiles of Korean Hanwoo Calves. Asian-Aust. J. Anim. Sci., 23(1): 52-60. 
Vahora, S.G., and Pande, M.B., 2006. Effect of enzyme supplementation on feed utilization, blood constituents and reproduction in dairy cows. Indian $J$. Animal Sci., 76(6): 471-475.

Williams, P.E.V., Tait, C.A.G., Innes, G.M., and Newbold, C.J. 1991. Effects of the inclusion of yeast culture (Saccharomyces cerevisiae plus growth medium) in the diet of dairy cows on milk yield and forage degradation and fermentation patterns in the rumen of steers. J. Animal Sci., 69, 3016-3026. Wohlt, J.E., Corcione, T.T., and Zajac, P.K. 1998. Effects of yeast on feed intake and performance of cows fed diets based on corn silage during early lactation. J. Dairy Sci., 81, 1345-1352.

Wohlt, J.E., Finkelstein, A.D., and Chung, C.H. 1991. Yeast culture to improve intake, nutrient digestibility, and performance by dairy cattle during early lactation. J. Dairy Sci., 74: 1395-1400.

\section{How to cite this article:}

Mayank Dubey, Vivek Pratap Singh, R.K. Pandey and Chaubey, A.K. 2017. Effect of Feed Additives on Nutrient Intake and Feed Efficiency of Lactating Crossbred Cows. Int.J.Curr.Microbiol.App.Sci. 6(2): 752-758. doi: http://dx.doi.org/10.20546/ijcmas.2017.602.083 